\title{
ENHANCED COOPERATION: IS THERE HOPE FOR THE UNITARY PATENT?
}

\begin{abstract}
Tihana Balagović
Summary: This paper reviews the use of enhanced cooperation in the creation of a European Union patent system. It assesses whether the legal requirements for the application of enhanced cooperation are fulfilled, and it does so in the light of the arguments raised by Italy and Spain in their actions for annulment brought before the European Court of Justice. The paper goes on to analyse whether the proposed patent system complies with the invoked legal basis, which requires the introduction of a new intellectual property right. If the answer is negative, possible ways to correct this mistake will be assessed.
\end{abstract}

\section{Introduction}

A single patent, uniformly valid for the entire territory of the European Union, has been desired for decades. Despite consensus on the need for such an instrument, Member States have still not reached unanimity regarding the exact specifics of such a European Union patent system.

Ultimately, twenty-five Member States resorted to the use of enhanced cooperation. This mechanism has existed ever since the Amsterdam Treaty, but has been used only once before - to regulate the conflict of law rules regarding divorce. ${ }^{1}$ Numerous scholars and experts were convinced that enhanced cooperation would never be applied because they had considered the legal requirements for such cooperation impossible to meet. ${ }^{2}$ Others were surprised at why such a powerful mechanism

\footnotetext{
Trainee lawyer. I would like to thank Dr Tamara Ćapeta for her advice as mentor in helping me prepare this paper during my studies at the Faculty of Law in Zagreb.

1 Council Decision 2010/405/EU of 12 July 2010 authorizing enhanced cooperation in the area of the law applicable to divorce and legal separation [2010] OJ L189/12.

2 For example, Eric Philippart and Monika Sie Dhian Ho, 'Flexibility and the New Constitutional Treaty of the European Union' (2003) Scientific Council for Government Policy; Eric Phillipparta, 'New Mechanism of Enhanced Cooperation for the Enlarged European Union' (2003) 22 Research and European Issues; Massimo Bordignon and Sandro Brusco, 'On Enhanced Cooperation' (2006) 90(10-11) Journal of Public Economics 2063; Norberto Nuno Gomes de Andrade, 'Enhanced Cooperation: The Ultimate Challenge of Managing Diversity in Europe: New Perspectives on the European Integration Process' (2005) 40(4) Intereconomics: Journal of European Economic Policy 201.
} 
was left aside and avoided. ${ }^{3}$ However, the opportunities to assess the application of the legal conditions for the use of enhanced cooperation have so far been scarce. ${ }^{4}$ The case of divorce mostly went under the radar, possibly because it merely provides couples with an additional option in choosing the applicable law, thus not touching others' interests and having no influential impact on the internal market.

This second case of enhanced cooperation may clarify some issues. Establishing a European Union patent in only some Member States is a highly controversial topic and raises numerous interesting questions important for the concept of enhanced cooperation. Can an instrument that is supposed to be a European Union instrument come into effect by means of enhanced cooperation? Does the circumstance that Italy and Spain, the only countries left behind, want to take part in the creation of a European Union patent prevent the rest of the Member States from proceeding without them? What impact is enhanced cooperation allowed to have on the internal market, as it is bound to have at least some detrimental effect on trade with non-participating Member States? Further, patents are a vital economic tool and may present a competitive advantage for participating Member States; is it acceptable for enhanced cooperation to run contrary to the economic interests of some Member States? Regardless of the financial issues, can a European Union act discriminate on the ground of language, given that the European Union recognises the importance of safeguarding cultural and linguistic diversity?

This article will reflect upon these latest questions and consider the arguments raised by Italy and Spain. Both countries filed actions with the European Court of Justice for the annulment of the decision authorising enhanced cooperation, claiming that enhanced cooperation does not comply with the necessary requirements. ${ }^{5}$

After an assessment of the formal conditions for enhanced cooperation, this article will review the legality of acts that are to be reached

\footnotetext{
3 For example, Daniel Thym, "'United in Diversity": The Integration of Enhanced Cooperation into the European Constitutional Order' in Philipp Dann and Micha Rynkowski (eds), The Unity of the European Constitution, (Beiträge zum ausländischen öffentlichen Recht und Völkerrecht, vol 186,Springer Berlin Heidelberg 2006); Julia De Clerck-Sachsse, Sebastian Kurpas, Gaëtane Ricard-Nihoul and José I Torreblanca, 'From Threat to Opportunity: Making Flexible Integration Work' (2006) 15 European Policy Institutes Network, Working Paper.

4 There are other examples of variable-geometry Europe and two-speed Europe, with the Schengen Area and Economic and Monetary Union as the most prominent examples. However, these cases did not apply the enhanced cooperation mechanism provided for by the Treaties, and thus may not be used for an interpretation of the legal requirements of enhanced cooperation.

5 Case C-274/11 Spain v Council [2011] OJ C219/12; Case C-295/ 11 Italy v Council [2011] OJ C232/22.
} 
through enhanced cooperation. It will analyse whether the proposed patent system complies with the invoked legal basis, which requires the introduction of a new intellectual property right. If the answer is negative, the article will assess possible ways to correct this mistake.

\section{Background}

At the moment, patent protection in the European Union can be obtained through national patents or European patents, but both systems have proven to be inadequate.

National patents suffer from the flaws inherent in a system governed by national laws. Rules governing the granting, existence and rights conferred by such patents differ between countries and have the effect only on the territory of the country in question, creating a complex network of patent protection for the same invention through the territory of the European Union. Moreover, in the case of infringement, the patent proprietor has to enforce his rights before each national court, as there is no mutual recognition of judgments in this area. The multiple procedures and language requirements of each country, particularly the requirement to publish the entire patent in the national language, result in high costs, while differences between national systems give rise to diverging decisions that create legal uncertainty and fragment patent protection in the internal market.

The European patent system shares the same problems. A European patent can be obtained for one or more of 38 European countries that are parties to the Convention on the Grant of European Patents, ${ }^{6}$ and that is done in a single granting procedure before the European Patent Office (hereinafter EPO). ${ }^{7}$ However, once a European patent is granted, it turns into a bundle of national patents. It has to be validated in each designated country with the payment of a validation fee to the national patent office and often by providing a translation of the patent into the national language. ${ }^{8}$ Afterwards, the existence and enforcement of the European patent are again wholly governed by the national laws. ${ }^{9}$

\footnotetext{
6 Convention on the Grant of European Patents of 5 October 1973 as revised by the Act revising Article 63 of 17 December 1991 and the Act revising the Convention of 29 November 2000 (European Patent Convention) (hereinafter EPC).

7 International organisation created by the EPC.

8 Art 65 para 1 EPC: 'Any contracting state may, if the European patent as granted, amended or limited by the EPO is not drawn up in one of its official languages, prescribe that the patent proprietor shall supply to its central industrial property office a translation of the patent as granted, amended or limited in one of its official languages at his option or, where that state has prescribed the use of one specific official language, in that language'.

9 Art 2 para 2 EPC: 'A European patent shall, in each of the contracting states for which it is granted, have the effect of and be subject to the same conditions as a national patent granted by that state, unless otherwise provided in the EPC'.
} 
It has been widely recognised that the current situation hinders innovation and hampers the integration of the internal market. A single European Union patent granted in one procedure without further requirements and having the same effect over the entire territory would put an end to these troubles. Unfortunately, this is more easily said than done.

Negotiations started in the 1960s, but the European Union patent has still not seen the light of day. The main issue is the question of abolishing the translation requirements and designating only some languages for patent applications and publications. Although this is necessary to lower the costs of patent protection, most of the Member States hesitate to give up their national language as an official patent language.

In 2009, it became clear that this impasse could not continue, especially with the economic situation calling for the stimulation of innovation and development. There then came a major breakthrough. It was agreed that the EPO would be endowed with the authority to grant European Union patents with effect throughout the Union territory, and that specialised patent courts with exclusive jurisdiction for patents would be established. ${ }^{10}$ However, the language regime was subjected to further discussion. ${ }^{11}$ The problems regarding translation reoccurred, and by the end of 2010 an agreement had still not been reached. The proposed system suggested the use of official EPO languages, namely English, German and French, but had 'fallen short of unanimity by a small margin.. ${ }^{12}$

In response, twelve Member States proposed the use of enhanced cooperation for the creation of a unitary patent, and were soon joined by another thirteen Member States, leaving out only Italy and Spain. With the approval of the European Parliament, the Council adopted a Decision authorising enhanced cooperation in the area of the creation of unitary patent protection. ${ }^{13}$

Enhanced cooperation is a mechanism provided for in the Treaties, which enables a group of a minimum of nine Member States to proceed

\footnotetext{
10 The issue of courts was another stumbling block when the European Court of Justice clarified that the proposed system would breach EU law. However, this lies outside the ambit of this paper. See Opinion of the Court 1/09 [2011] ECR 00000.

11 Europa, 'Patents: EU achieves political breakthrough on an enhanced patent system', Press Release IP/09/1880 of 4 December 2009 <http://europa.eu/rapid/pressReleasesAction.do?reference $=I P / 09 / 1880 \&$ type $=H T M L \&$ aged $=0$ \&language $=E N \&$ guiLanguage $=f r>$ ac cessed 29 March 2012.

12 Council of the European Union Press Release 16041/10 of 10 November $2010<\mathrm{http}$ // www.consilium.europa.eu/uedocs/cms_data/docs/pressdata/en/intm/117687.pdf> accessed 29 March 2012.

13 Council Decision 2011/167/EU of 10 March 2011 authorizing enhanced cooperation in the area of the creation of unitary patent protection [2011] OJ L76/53 (hereinafter Authorising Decision).
} 
with integration in a certain area if concerted action proves impossible. The decisions reached through enhanced cooperation are applicable only in the participating Member States. When enhanced cooperation is used, a minimum of two decisions are needed. The first one is a decision authorising enhanced cooperation, proposed by the Commission, approved by the European Parliament, and reached by the Council acting unanimously but with only the participating Member States having the right to vote.

The second one is a decision implementing the authorised enhanced cooperation by adopting substantive provisions and using the relevant Treaty procedures, also with only the participating Member States taking part in the vote. ${ }^{14}$

In the case of unitary patent protection, the Authorising Decision allowed the use of enhanced cooperation, and forms the ground for two implementing decisions: the decision creating unitary patent protection and the decision on translation agreements for such protection. ${ }^{15}$ At the moment, these are in the phase of proposals, namely the Proposal for a Regulation implementing enhanced cooperation in the area of the creation of unitary patent protection, and the Proposal for a Regulation implementing enhanced cooperation in the area of the creation of unitary patent protection with regard to applicable translation arrangements. ${ }^{16}$ However, the Authorising Decision refers to the current versions of the proposals, thus making them eligible for assessment.

In its current version, the Unitary Patent Protection Proposal still envisages that the EPO will grant patents in accordance with the EPC, but provides the option of designating the entire territory of the twentyfive participating Member States. ${ }^{17}$ If this is done, the European patent will have a unitary effect in the area, thus being limited, transferred, revoked or allowed to lapse in respect of all these states. ${ }^{18}$ Moreover, once

\footnotetext{
14 Arts 329 and 330 of the Treaty on the functioning of the European Union as amended by the Treaty of Lisbon (2007) (hereinafter TFEU).

15 Separate decisions are necessary because the Treaty prescribes a different legislative procedure for establishing measures that create unitary intellectual property rights from the translation agreements regarding these rights. See art 118 TFEU.

16 Proposal COM/2011/215 of 13 April 2011 for a Regulation of the Council and the European Parliament implementing enhanced cooperation in the area of the creation of unitary patent protection (hereinafter Unitary Patent Protection Proposal or UPPP); Proposal COM/2011/216 of 13 April 2011 for a Regulation of the Council and the European Parliament implementing enhanced cooperation in the area of the creation of unitary patent protection with regard to the applicable translation arrangements (hereinafter Translation Proposal or TP).

17 Art 2 c) UPPP (n 16).

18 Art 3 UPPP (n 16).
} 
this European patent with unitary effect is granted and registered at the $\mathrm{EPO}$, no further national requirements apply. ${ }^{19}$

This is in line with the Translation Proposal, which abolishes the option of requiring further national translations after the application and publication are made in English, French or German. This system will apply after a transitional period lasting a maximum of twelve years. During the transitional period, patents with French or German as the language of the proceedings will have to be submitted with a full translation in English, and ones with English will have to be submitted with a full translation into any language of the participating Member States that is an official language of the Union. The point of the transitional period is to wait for the availability of high quality translation machines, which will then translate patent applications into all the official languages of the Union. Until then, all applicants filing a patent application at the EPO in one of the Union languages and not in an official EPO language will have their translation costs reimbursed up to a ceiling. ${ }^{20}$

\section{Authorisation Decision - the legality of enhanced cooperation}

\section{III.1. Non-exclusive competence of the EU}

The areas eligible for enhanced cooperation are defined in the first paragraph of Article $20 \mathrm{TEU},{ }^{21}$ which stipulates:

Member States which wish to establish enhanced cooperation between themselves within the framework of the Union's non-exclusive competences may make use of its institutions and exercise those competences by applying the relevant provisions of the Treaties ...

Therefore, to use enhanced cooperation in the area of unitary patent protection, the creation of such protection must be a non-exclusive competence of the Union. Article 118 TFEU provides for powers to establish European intellectual property, ${ }^{22}$ and the Authorising Decision invokes

\footnotetext{
19 Art 10 para 4 UPPP (n 16).

20 Art 6 TP (n 16).

${ }^{21}$ Treaty on the European Union as amended by the Treaty of Lisbon (2007) [2010] OJ C83/13 (hereinafter TEU) (emphasis added).

22 Art 118 TFEU (n 14): 'In the context of the establishment and functioning of the internal market, the European Parliament and the Council, acting in accordance with the ordinary legislative procedure, shall establish measures for the creation of European intellectual property rights to provide uniform protection of intellectual property rights throughout the Union and for the setting up of centralized Union-wide authorization, coordination and supervision arrangements. The Council, acting in accordance with a special legislative procedure, shall by means of regulations establish language arrangements for the European intellectual property rights. The Council shall act unanimously after consulting the European Parliament'.
} 
it as a legal basis for the unitary patent. Both Spain and Italy submitted pleas claiming that the European Union has exclusive competence to create European intellectual property rights, thus leaving article 118 TFEU out of the scope of enhanced cooperation. ${ }^{23}$

Article 118 TFEU identifies its own framework, by defining that the measures it provides for are to be introduced in the context of the establishment and functioning of the internal market. Accordingly, the introduction of new intellectual property rights should be perceived as an internal market matter, and the internal market is a shared competence of the Union. ${ }^{24}$

Moreover, the creation of unitary patent protection is not mentioned under the Union's exclusive competences. These are listed in article 3 TFEU, and include the areas of customs union, establishing the competition rules necessary for the functioning of the internal market, monetary policy for the Member States whose currency is the euro, conservation of marine biological resources under the common fisheries policy, and the common commercial policy.

Of this exhaustive list, ${ }^{25}$ patents are related only to competition and common commercial policy. Regarding common commercial policy, intellectual property rights are closely linked to the trade in products and services to which they apply. ${ }^{26}$ However, article 207 TFEU restricts the scope of common commercial policy to the commercial aspects of intellectual property rights. ${ }^{27}$ This novelty, introduced in the Lisbon Treaty, prevents the Council from expanding the area of common commercial policy to non-commercial features of intellectual property. ${ }^{28}$ The creation of unitary patent protection does not, by any means, regulate the traderelated aspects of patents. ${ }^{29}$

\footnotetext{
23 Spain (n 5) point 3.2; Italy (n 5) first argument.

24 Art 4 para 2 point a) TFEU (n 14).

25 Amedeo Arena, 'The Doctrine of Union Preemption in the EU Single Market: Between Sein and Sollen' (2010) Jean Monnet Working Paper 03/10, $11<$ http://centers.law.nyu. edu/jeanmonnet/papers/10/100301.pdf> accessed 9 March 2012.

26 Opinion of the Court 1/94 [1994] ECR I-05267 para 54.

27 Art 207 TFEU (n 14): 'The common commercial policy shall be based on uniform principles, particularly with regard to changes in tariff rates, the conclusion of tariff and trade agreements relating to trade in goods and services, and the commercial aspects of intellectual property...'.

28 Markus Krajewski, 'The Reform of the Common Commercial Policy' in A Biondi and P Eeckhout (eds), European Union Law after the Treaty of Lisbon (OUP 2012) 14 available at <http://www.europarl.europa.eu/document/activities/cont/201012/20101207ATT 07788/20101207ATT07788EN.pdf> accessed 9 March 2012.

29 Steve Peers, 'The Constitutional Implications of the EU Patent' (2011) 7 European Constitutional Law Review 229, 251.
} 
As for the issue of competition, patents are a state-approved monopoly, and there is a body of case law created by the European Court of Justice concerning the relation between competition rules and intellectual property rights. ${ }^{30}$ Nevertheless, the Unitary Patent Protection Proposal does not deal with this aspect of patents either. ${ }^{31}$ It has a special provision stipulating that unitary patent protection is to be without prejudice to the application of competition law and law relating to unfair competition. It also omits to regulate compulsory licensing, the most prominent institute dealing with the impact intellectual property has on competition. ${ }^{32}$

Even if the proposal included compulsory licenses, ${ }^{33}$ it would still not fall under the area of the regulation of competition. In the architecture of the TFEU, article 118 falls under the title dealing with approximation of laws, together with article 114 which is used as a legal basis for harmonisation. ${ }^{34}$ Both article 114 TFEU and article 118 TFEU delineate improvement in the functioning of the internal market as their objective, and their application should be assessed in the light of whether a legal act shares that intent, regardless of the potential ancillary impact it has on neighbouring areas. ${ }^{35}$ The main idea behind unitary patent protection is to facilitate patents that are uniformly valid over the entire territory of the internal market. In this way, a supposedly single market would not be partitioned into 27 different territories, as is now the case with only national patents and with patent protection beginning and ending at each national border. ${ }^{36}$ Unitary patent protection therefore aims to achieve better integration of the internal market and falls under the shared competences of the EU. ${ }^{37}$

The exhaustive list of exclusive competences was introduced, at the same time as Article $118 \mathrm{TFEU}$, by the Lisbon Treaty. If the creation of new forms of intellectual property was meant to be an exclusive competence, it would have been explicitly mentioned under Article 3 TFEU, or would have implicitly fallen under the areas enumerated therein.

Still, Italy argues that only the EU can introduce European rules required to create 'European intellectual property rights' to which article

\footnotetext{
30 For instance, see Case T-201/04 Microsoft [2007] ECR II-03601 and Case T-321/05 AstraZeneca [2010] ECR 0000.

31 Peers (n 29) 251.

32 Art 19 UPPP (n 16).

33 As suggested in IV below.

34 Part 3 Title VII TFEU (n 14).

35 See Case C-376/98 Tobacco Advertising [2000] ECR I-08419.

36 Victor Rodriguez, 'Constructing a Unitary Title Regime for the European Patent System' (2011) 6(8) Journal of Intellectual Property Law \& Practice 574, 579.

37 On whether it actually achieves this, or raises a contrary effect, see III. 4.
} 
118 TFEU refers, thus elevating it to a de facto exclusive competence of the Union. First of all, enhanced cooperation is limited to non-exclusive competences because all Member States agreed to completely transfer their sovereignty in areas of exclusive competences to the European Union. Consequently, they are not permitted to regulate these issues on their own, not even by using enhanced cooperation. ${ }^{38}$ The existence of de facto exclusive competence does not entail a loss of sovereignty, so it should not prevent the use of enhanced cooperation.

Secondly, article 118 TFEU provides authorisation to 'establish measures for the creation of European intellectual property rights to provide uniform protection throughout the Union'. This came into existence as an explicit recognition of the Union's competence to introduce new forms of supra-national intellectual property, which previously had to be adopted under the residual legal basis of article 352 TFEU. ${ }^{39}$ Therefore, reference to the creation of European intellectual property rights can be understood as an emphasis of their transnational autonomous character, and an indication of the Union's territory as a necessity to achieve uniform protection. There are no obstacles preventing Member States from creating sui generis supranational intellectual property rights having unitary effect throughout their territories, and consequently over the territory of the European Union. There is also no reason why these rights would not be European intellectual property rights, such as the European patent that already exists outside the scope of the EU. Article 118 TFEU indisputably presents an appropriate ground for the creation of European intellectual property, but it does not itself vest the European Union with exclusive competence for the creation of new intellectual property having effect over the Union's territory. ${ }^{40}$ Embarking on the creation of such rights could prove to be more appropriate at the EU level, but this does not imply exclusive competence; it amounts to compliance with the principle of subsidiarity. The principle of subsidiarity governs the EU's actions in the field of shared competences by allowing the EU to act only when such actions are better achieved at the Union level. ${ }^{41}$ If all issues benefiting from the involvement of the European Union were considered an exclusive competence, the use of enhanced cooperation would be prohibited in the entire area of shared competences, contrary to the expression 'non-exclusive' used in article 20 TEU.

\footnotetext{
38 Carlo Maria Cantore, 'We're One, But We're Not the Same: Enhanced Cooperation and the Tension between Unity and Asymmetry in the EU' (2011) 3(3) Perspectives on Federalism 7 <http://ssrn.com/abstract=2006513> accessed 3 March 2012.

39 See IV. 1 below.

40 See by analogy of the implied competences, Opinion of the Court 1/94 [1994] ECR I05267, para 100.

41 Art 5 para 3 TEU (n 21).
} 
Even if article 118 TFEU referred to 'European Union intellectual property rights', which it does not, this would be only natural. Instruments established by the European Union are to be European Union instruments, and no one but the European Union can do this. This does not mean that every action involving the European Union, every legal basis referring to a European Union institute or every mention of the Union's territory should be considered outside the scope of enhanced cooperation. Article 20 TEU unambiguously authorises Member States taking part in enhanced cooperation to exercise the Union's competences and use the Union's institutions. Although they are regularly used by the Union as a whole and are thus referred to as the Union's, this does not prevent a group of Member States from utilising them. Enhanced cooperation is in its spirit an exception to the rule. Moreover, it was never used before the Lisbon Treaty, although it has been provided for since the Amsterdam Treaty. It would be inappropriate to expect that provisions of the Treaty count on the use of enhanced cooperation and thus omit indicating the European Union in their wording. It would be equally tenuous to rely on the mention of the European Union as a whole in order to preclude the use of enhanced cooperation, if all other requirements are met. $^{42}$

Ultimately, competence for the creation of European intellectual property titles can be categorised as an internal market competence and hence as a shared competence, without entailing the loss of sovereignty regarding national legislation. ${ }^{43}$ Therefore, enhanced cooperation in the area of the creation of unitary patent protection complies with the requirement of being established within the framework of the Union's nonexclusive competences.

\section{III.2. Last resort}

Enhanced cooperation can be a powerful tool for overcoming a political impasse. ${ }^{44}$ However, it should not be used to circumvent legislative procedures in cases of simple disagreements over policy choices, as that

\footnotetext{
42 For whether the aim and effect of art 118 TFEU can be preserved through enhanced cooperation, see III.4 below.

43 Maximilian Brosinger and others, 'IP Law Reform and the Treaty of Lisbon' (1 September 2008)

Max Planck Institute for Intellectual Property, Competition \& Tax Law Research Paper, No 09-03 <http://papers.ssrn.com/sol3/papers.cfm?abstract_id=1340861> accessed 3 March 2012.

44 Cantore (n 38) 10, quoting Craig Paul, 'The Lisbon Treaty: Law, Politics and Treaty Reform' (OUP 2010).
} 
would jeopardise the institutional balance within the EU. ${ }^{45}$ The second paragraph of article 20 TEU safeguards against that:

The decision authorizing enhanced cooperation shall be adopted by the Council as a last resort, when it has established that the objectives of such cooperation cannot be attained within a reasonable period by the Union as a whole.

A group of Member States can have recourse to the use of enhanced cooperation only if the concerted action of all Member States proves impossible. Italy claims that the Authorising Decision was adopted without an appropriate inquiry regarding the last resort condition and without an adequate statement of reasons. ${ }^{46}$ Spain issued a similar plea, and complemented it by claiming that enhanced cooperation amounts to a misuse of power, since the objective of creating unitary patent protection could have been achieved by means of a special agreement provided for in article $142 \mathrm{EPC}^{47}$ Italy and Spain generally seek to take part in the creation of unitary patent, but they oppose the proposed languages system. They agree with the policy, but are left behind on account of the linguistic matters. ${ }^{48}$ Therefore, the real question seems to be whether it is necessary for cooperation of the Union as a whole to be impossible because some Member States are unwilling to integrate in the area or are or even incapable of doing so, or whether it is it enough for cooperation to be impossible on account of differing opinions and lack of agreement. ${ }^{49}$

When the Amsterdam Treaty introduced enhanced cooperation, then called 'closer cooperation', the last resort principle was worded to emphasise inability to attain the Union's objectives, stating that enhanced cooperation 'is only used as a last resort, where the objectives of the said Treaties could not be attained by applying the relevant procedures laid down therein'. ${ }^{50}$ This was in line with enhanced cooperation coming into existence as an institutional response to the progressive enlargement of the EU, as the EU began to encompass countries vastly diverging in their economic and institutional background. ${ }^{51}$ The core idea of enhanced cooperation was to strike a balance between countries that are able and

\footnotetext{
45 Thomas Jaeger, 'All Back to Square One? An Assessment of the Latest Proposals for a Patent and Court for the Internal Market and Possible Alternatives' (2012) Max Planck Institute for Intellectual Property and Competition Law Research Paper, No 12-01, 6.

46 Spain (n 5) third argument.

47 Italy (n 5) points 1 and 3.1.

48 Cantore (n 38) 13.

49 Jaeger (n 45) 6.

50 Art 43 para 1 c) TEU (n 21) (emphasis added).

51 Cantore (n 38) 5.
} 
willing to foster further integration, and countries that are not. ${ }^{52}$ If such discrepancies were to endanger the very objective of the Union, enhanced cooperation could provide a solution.

The Nice Treaty kept the last resort principle, but changed its wording to stipulate that:

[E]nhanced cooperation may only be set up when it has been established within the Council that the objectives of such cooperation cannot be attained within a reasonable period by applying the relevant provisions of the Treaties. ${ }^{53}$

This amendment focuses on the enhanced cooperation objectives rather than the EU and Treaties objectives, thus emphasising that such a mechanism would be used as a solution in the case of a political deadlock. Enhanced cooperation is in its current version perceived as a method to avoid any severe decision-making paralysis, rather than as an instrument for advancement in policy areas where only some Member States find it acceptable to integrate. ${ }^{54}$ The provision remained the same in the Lisbon Treaty, and it does not by any means imply that the reasons why the objectives of an action cannot be attained play a role when deciding whether the condition of last resort is satisfied. Therefore, it should be considered fulfilled if an agreement cannot be attained in the foreseeable future, and not only when Member States reject the very idea of the proposed policy. ${ }^{55}$

The first authorisation of enhanced cooperation confirms this approach. Its implementing act is the Rome III Regulation, which approximates conflict of law rules in the matter of divorce. ${ }^{56}$ TFEU prescribes a special legislative procedure, with the Council acting unanimously for the adoption of rules on family law with cross-border implications. ${ }^{57}$ It was impossible to reach unanimity as some Member States opposed the Regulation in so far as it occasionally provided for the application of foreign divorce law. It was mostly the Scandinavian states which share a liberal approach to divorce that did not consider it appropriate to ap-

\footnotetext{
52 ibid, quoting Bribosia (2007).

53 Art 43 para 1 a) TEU (n 21) (emphasis added).

54 Dragos Negrescu and Gilda Truica, 'Can EU's Enhanced Cooperation Mechanism Provide Solutions to the "Single Undertaking" Problems of the WTO?' (2006) 6(2) Romanian Journal of European Affairs 5, 15 <http://www.ier.ro/documente/rjea_vol6_no2/RJEA_Vol6_No2_ Can_the_EUs_Enhanced_Co-operation_Mechanism_Provide_Solutions_to_the_"Single_Undertaking”_Problems_of_the_WTO.pdf> accessed 9 March 2012.

55 Peers (n 29), 259.

56 Council Regulation 1259/2010/EU of 20 December 2010 implementing enhanced cooperation in the area of the law applicable to divorce and legal separation [2010] OJ L343/10.

57 Art 81 para 2 TFEU (n 14).
} 
ply more restrictive laws. ${ }^{58}$ It should be noted that they did not oppose approximation in the field of family law itself, but they considered that it should provide more flexibility to satisfy the concerns of all Member States. Therefore, there was a consensus regarding the policy, but a disagreement regarding its substance. The Rome III Regulation has not so far been contested and there are sufficient reasons to believe that enhanced cooperation met the legal requirements. ${ }^{59}$

The fact that Italy and Spain want to take part in the Unitary Patent Proposal and the Translation Proposal, but not under the given conditions, should thus not be taken into account when assessing the condition of last resort. ${ }^{60}$

Spain claims that enhanced cooperation would amount to misuse given that other options are available outside the European Union. However, this claim seems misplaced. In all situations eligible for enhanced cooperation, namely in the areas of non-exclusive competences, there is an option of intergovernmental agreement between willing Member States. The point of the claim is not that either Italy or Spain would join such a special agreement under the current conditions and thus facilitate a higher level of unity, but just that enhanced cooperation is not the only choice for achieving unitary patent protection between twenty-five Member States. ${ }^{61}$ The second paragraph of article 20 TEU permits the use of enhanced cooperation as a last resort option, and unequivocally defines last resort as a situation where 'the objectives of such cooperation cannot be attained within a reasonable period by the Union as a whole', not as a situation where no other options outside the Union exist. The assessment of the availability of enhanced cooperation should thus be restricted to asserting whether it is feasible to expect an agreement to be reached at the EU level in the foreseeable future.

As for the unlikelihood of attaining unitary patent protection within a reasonable time, it should suffice to say that the history of cumbersome efforts to create a European patent with transnational unitary effect

\footnotetext{
58 Commission, Proposal for a Council Decision No .../2010/EU authorising enhanced cooperation in the area of the law applicable to divorce and legal separation, $\operatorname{COM}(2010)$ 104 final, point 4.

59 Steve Peers, 'Divorce, European Style: The First Authorization of Enhanced Cooperation' (2010) 6 European Constitutional Law Review 339.

60 See by analogy the Court of Justice's ruling that a non-participant in the Schengen acquis cannot demand that the other Member States amend draft legislation building on that acquis so that it can participate. Case C-482/08 UK v Council [2010] ECR 00000.

${ }^{61}$ Italy and Spain opposed the trilingual language system from the beginning, and there are no reasons to believe that their attitude would change with agreement being concluded outside the EU.
} 
goes even further back into the past than the European Union itself; ${ }^{62}$ it started in 1957, and is so far without success. ${ }^{63}$ The intergovernmental approach, taken up to the 1990s, resulted in the Community Patent Convention from $19766^{64}$ and its amendment from $1989,{ }^{65}$ both signed but never ratified. They were meant to introduce a single Community Patent uniformly valid over the entire territory, but they failed because of a disagreement over the issue of translations. The requirement remained of filing national translations and thus did not meet the standard of cost effectiveness. Based on the position taken in the Commission Green Paper in $1997,{ }^{66}$ the approach changed from that of an intergovernmental agreement to a European Union Regulation, resulting in the Community Patent Regulation Proposal. The first draft in $2000^{67}$ contained a language system similar to the current Translation Proposal. It was widely supported by industry, but was not politically acceptable. The second draft in $2004^{68}$ changed the language regime to require translations in all national languages. This resulted in the loss of support from industry because of the lack of added value, and the proposal was finally rejected in 2004 after no consensus was reached in the Council. The issue was re-launched in 2007,69 with the Translation Proposal in $2010^{70}$ abolishing the requirement of national translations, in line with the Community Patent Regulation Proposal of 2000. Despite several Council meetings, it has proved impossible to reach a unanimous agreement and this has led to the currently approved enhanced cooperation.

Not only has the issue of unitary patents been thoroughly discussed over the last 60 years, but the proposed translation system solution has also existed ever since the Community Patent Proposal of 2000. Just for comparison, the debate over approximating the conflict of law rules

62 Van Empel, 'The Granting of European Patents: Introduction to the Convention on the Grant of European Patents' (AW Sijthoff 1973) ch 1.

${ }_{63}$ Thomas Jaeger, 'The EU Patent: Cui bono et quo vadit?' (2010) 47 CML Rev 63.

${ }_{64}$ Convention 76/76/EEC of the 5 October 1973 for the European Patent for the common market, [1976] OJ L17/1.

65 Agreement 89/695/EEC of 15 December 1989 relating to Community patents [1989] OJ LAO1/1.

66 Green Paper COM/97/314 of 24 June 1997 on the Community patent and the patent system in Europe.

67 Commission, Proposal for a Council Regulation on the Community patent COM (2000) 412 final.

68 Preparation $7119 / 04$ of 8 March 2004 for the meeting of the Council on 11 March 2004.

69 Commission, 'Enhancing the patent system in Europe' (Communication) COM (2007) 165 final.

70 Commission, 'Proposal for a Council Regulation on the translation arrangements for the European Union patent' COM (2010) 350 final. 
regarding divorce lasted from the Green Paper in 2005 to the request for enhanced cooperation in 2008 , and in that case three years were considered sufficient to find that there were insurmountable difficulties!

Last resort is, of course, not just a matter of the years spent negotiating, but when it comes to the unitary patent and solutions for its translations, the fact that all viable options have already been discussed over a lengthy period of time. If consensus could have been reached, there were enough situations at hand to find it. Nothing in the past or present situation gives ground to believe that agreement could be made in the foreseeable future by the Union as a whole. Consequently, there should be no doubt about the unitary patent fully satisfying the condition of last resort.

\section{III.3. Discrimination}

Enhanced cooperation derogates from the Treaties only so far as they prescribe the legislative procedures necessary to adopt certain decisions, and that is mitigated by making the enhanced cooperation acts binding just for the participating Member States. ${ }^{71}$ The rest of the Treaties and EU rules still regularly apply, as stated in the first paragraph of article 326 TFEU: 'Any enhanced cooperation shall comply with the Treaties and Union law'. Therefore, it should be assessed whether the Authorising Decision and implementing proposals violate EU law and its principles.

The most controversial element of unitary patent protection is the question of language. The Translation Proposal suggests a general rule under which patent applications can be made only in English, French or German, with no additional translation requirements allowed.

Italy and Spain claim that this trilingual system violates the principle of non-discrimination. ${ }^{72}$ Freedom from discrimination is a core value of the European Union, ${ }^{73}$ and the Charter of Fundamental Rights explicitly prohibits any discrimination based on the ground of language. ${ }^{74}$ Moreover, a separate article of the Charter emphasises respect for lan-

\footnotetext{
71 Art 20 para 4 TEU (n 21).

72 Spain (n 5) point 3.2; Italy (n 5) last argument.

73 Ian Bryan, 'Equality and Freedom from Discrimination: Article 13 EU Treaty' (2002) 24(2) Journal of Social Welfare and Family Law 223 <http://papers.ssrn.com/sol3/papers. cfm?abstract_id=1423842> accessed 2 March 2012.
}

${ }^{74}$ Art 21 of the Charter of Fundamental Rights [2010] C83/389 (hereinafter Charter): 'Any discrimination based on any ground such as sex, race, colour, ethnic or social origin, genetic features, language, religion or belief, political or any other opinion, membership of a national minority, property, birth, disability, age or sexual orientation shall be prohibited'. 
guage diversity ${ }^{75}$ Therefore, it should be reviewed whether a restriction to only three languages amounts to discrimination and disrespect regarding the remaining twenty Union languages.

The Court has already ruled that a similar language regime of the Community Trademark Regulation does not fall under the scope of the principle of non-discrimination. ${ }^{76}$ The regulation designates English, Italian, French, German and Spanish as official languages, and was contested for allegedly discriminating against all other languages. The Court has in both instances held that the Treaties' references to the use of languages do not form a general principle of law which would confer a right on every citizen to "have a version of anything that might affect his interests drawn up in his language in all circumstances'. ${ }^{77}$ At the time of the judgment, the Treaties included the general principle of nondiscrimination, as well as rules providing citizens of the Union with a right to correspond with the Union's institutions in any Union language. However, the Charter did not exist at that point, and its explicit mention of language may have broadened the applicable scope of discrimination.

If the proposed language system does present an a priori case of language discrimination, attention should be paid to the Charter's provision on the scope and interpretation of rights and principles. Article 52 of the Charter permits the limitation of rights recognised by the Charter if certain conditions are met. Such limitation must be provided for by law, must respect the essence of rights in question, and must be subjected to the principle of proportionality. In the case of a limitation of certain fundamental rights, the applicable principle of proportionality requires that the limitations are necessary, that they genuinely meet the objectives of general interest recognised by the Union, and that they comply with proportionality stricto sensu - meaning that the limitation is proportionate to the pursued aim. ${ }^{78}$

The Translation Proposal is based on the second paragraph of article 118 TFEU, which authorises the establishment of language ar-

\footnotetext{
75 Art 22 Charter (n 74): 'The Union shall respect cultural, religious and linguistic diversity'.

76 Case C-361/01 P Kik [2003] ECR I-8283, upholding the Court of First Instance judgment in Case T-120/99 Kik [2001] ECR II-2235.

77 ibid, para 82 .

78 Art 52 Charter (n 74): 'Any limitation on the exercise of the rights and freedoms recognized by this Charter must be provided for by law and respect the essence of those rights and freedoms. Subject to the principle of proportionality, limitations may be made only if they are necessary and genuinely meet objectives of general interest recognized by the Union or the need to protect the rights and freedoms of others' (emphasis added).
} 
rangements regarding European intellectual property rights. ${ }^{79}$ The term 'language arrangement' entails the possibility of restraining from the use of all national languages, otherwise a special arrangement would not be needed. Moreover, article 118 was drafted with the EU patent in mind. ${ }^{80}$ As it was already clear that translation costs must be reduced, the second paragraph was added to subject language limitations to unanimity in the Council, thus making them binding only for the consenting Member States. At the time this provision was adopted, the current trilingual model had already been tabled. ${ }^{81}$ Therefore, the limitation of languages used for patents is founded on law. It falls under article $118 \mathrm{TFEU}$, which was both drafted and adopted in the light of such language arrangements.

With regard to respecting the essence of language diversity, it would be very difficult to argue that the technical language of patents reflects the essence of multilingualism. Patents do not embody a culture, and the limitation of languages in patent applications does not result in a loss of tradition or national identity. ${ }^{82}$ As Steve Peers poetically puts it, it can hardly be claimed that the richness of languages of Cervantes and Dante is dependent upon their use in patent claims'. ${ }^{83}$

As for necessity, the high cost of patent protection in the European Union is considered to be one of the main drawbacks of the existing system, and patent users univocally emphasise the need for cost reduction. ${ }^{84}$ At the moment, obtaining patent protection in thirteen Member States costs EUR 12,500, and rises to over EUR 32,000 if obtained for

\footnotetext{
79 Art 118 TFEU (n 14): 'The Council, acting in accordance with a special legislative procedure, shall by means of regulations establish language arrangements for the European intellectual property rights. The Council shall act unanimously after consulting the European Parliament'. .

80 See, for example, Report Session of House of Lords' European Union Committee <http:// www.publications.parliament.uk/pa/ld200708/ldselect/ldeucom/62/62.pdf > accessed 7 March 2012.

81 That is, by adopting the Lisbon Treaty.

82 Jason R Riley, 'The Community Patent, Or: How I Learned to Stop Worrying and Love the English Language' (2002) 18 (2) Santa Clara Computer \& High Technology Law Journal 299, 304 <http://digitalcommons.law.scu.edu/chtlj/vol18/iss2/6> accessed 5 March 2012.

83 Peers (n 29) 256.

84 For small and medium enterprises, see Commission, 'Think Small First - A Small Business Act for Europe, Communication' (Communication) COM (2008) 0394 final; European Association of Craft, Small and Medium-sized Enterprises (UEAPME) 'Expectations on the Proposal for a European Small Business Act' <www.ueapme.com> accessed 5 March 2012; Association of European Chambers of Commerce and Industry, 'Response to the Consultation on a Small Business Act for Europe' <http://www.eurochambres.eu> accessed 5 March 2012. For results of consultations with stakeholders, see Commission, 'Questionnaire on the Patent System in Europe'; and Commission, 'Future Patent Policy in Europe - Public Hearing on 12 July 2006' available at <http://ec.europa.eu/internal_market/indprop/patent/consultation_en.htm> accessed 5 March 2012.
} 
the entire EU territory. Overall expenses of patent protection in the EU amount to approximately EUR 193 million per year. ${ }^{85}$ Furthermore, a patent is on average validated in only five Member States, ${ }^{86}$ as the translation in five languages alone costs more than obtaining a patent in the US or Japan, ${ }^{87}$ thus making patent protection in the EU about ten times more expensive than in the latter countries. ${ }^{88}$ With $70 \%$ of the total costs being translation costs, ${ }^{89}$ if there is any prospect for accessible, affordable and wider-reaching patent protection, the issue of language translation must be tackled. In this light, the idea of keeping the requirement for the translation of a patent application or even only patent claims into all the Union languages was unanimously rejected. ${ }^{90}$ Consequently, the restriction of language diversity in patent applications is necessary to establish an efficient EU patent system, until high quality translation machines become available.

The Translation Proposal keeps the EPO language system in place by adopting its official languages. The Unitary Patent Protection Proposal delegates the granting of patents to the EPO; if EPO procedures are used, maintaining their already established language system seems rational and makes an objective distinction between languages. ${ }^{91}$ Reasons that are even more substantial distinguish English, French and German from the pool of twenty-three Union languages when it comes to patent applications. According to EPO statistics over the last ten years, Germany is without doubt the European country with most patent applications, starting with over 26,000 in 2001 and rising to 33,000 in 2010. ${ }^{92}$ France is second, with steadier progress, starting from 8,000 in 2001, reaching 11,000 in 2010; the United Kingdom is next, with approximately 7,000

\footnotetext{
85 Impact Assessment, Commission staff working paper SEC/2011/482, 13 April 2011, 16.

86 For example, 'Study on the Cost of Patenting in Europe' (2004) prepared on behalf of the EPO by Roland Berger Market Research.

87 Commission, 'Think Small First - A Small Business Act for Europe' (Communication) COM (2008) 0394 final.

88 Didier François, Bruno van Pottelsberghe de la Potterie, 'The Cost Factor in Patent Systems' (2006) Université Libre de Bruxelles Working Paper WP-CEB 06-002, $17<$ https:// dipot.ulb.ac.be:8443/dspace/bitstream/2013/6307/1/bvp-0063.pdf> accessed 5 March 2012.

89 Commission (n 69).

90 Commission (n 87); ICC Policy statement: The EC Green Paper of 5 November 1997 on the Community Patent and the Patent System in Europe <http://www.iccwbo.org/id374/ index.html> accessed 17 March 2012.

${ }^{91}$ On whether EPO system should be maintained without further changes, see IV.5 and IV.6. However, these assertions do not apply to the question of language.

92 Austria's 2,000 application per year should be added to German applications, as they are also in German; Denmark, the Netherlands and Sweden have nominated English for translations of their applications, so they should be added to the number of applications in English (although with a reservation).
} 
applications each year. For comparison, Italy has 4,000, and Spain barely reaches 2,000 applications per year. Only the Netherlands comes close to the number of UK applications, and the Netherlands has designated English as the language for patent applications. ${ }^{93}$ All other European countries fall way back. ${ }^{94}$ Designating the languages of the countries that are most active in using the patent system as languages for the application of the unitary patent seems therefore to be a clear and objective criterion which represents the least restrictive option. With models that would require translation into all the Union's languages not being feasible, there is no less restrictive option than to limit the languages to those that are most used in the patent system.

The introduction of the unitary patent protection system aims at promoting scientific and technological advances, a general objective of the Union recognised in article 3 TEU. Patents are crucial for innovation; they provide an incentive for the dissemination of ideas and increase the activity of the research and development sector. ${ }^{95}$ Moreover, they facilitate economic growth and are becoming a crucial aspect of business. ${ }^{96}$ The European Union has recognised the importance of intellectual property numerous times: the Europe 2020 Strategy aims towards an economy based on knowledge and innovation, which is to result in high levels of employment, productivity and social cohesion; ${ }^{97}$ and the Single Market Act emphasises that the internal market must encourage as much as it can innovation and creativity in order to face international competition. ${ }^{98}$ An efficient patent system is hence a legitimate aim for the European Union to pursue. The proposed system would lower the translation costs to EUR 680 for the entire area of the European Union, thus bringing the expenses down to $2 \%$ of the current price and saving EUR 49 to 65.2 million when compared to the present system. ${ }^{99}$ Studies have shown that such cost reduction leads to an increase in patent filings, ${ }^{100}$ which makes this strategy suitable for reaching the Union's objectives.

\footnotetext{
93 EPO statistics, filing 2001-2010 per country of residence of the applicant.

94 ibid.

95 Dominique Guellec, Bruno van Pottelsberghe de la Potterie, 'The Economics of the European Patent System' (OUP 2007); 'Patents and Innovation: Trends and Policy Challenges' OECD 2004 <http://www.oecd.org/dataoecd/48/12/24508541.pdf> accessed 17 March 2012.

96 Eurostat data 2008 <http://www.oceantomo.com/productsandservices/investments/ indexes/ot300> accessed 17 March 2012.

97 Commission 'Europe 2020' COM (2012) 299 final.

98 Commission, Single Market Act' COM (2012) 573 final.

99 Commission (n 87).

100 Jérôme Danguy, Bruno Van Pottelsberghe, 'Patent Fees for a Sustainable EU (Community) Patent System' <http://ec.europa.eu/internal_market/indprop/patent/index_ en.htm> accessed 17 March 2012.
} 
When it comes to proportionality stricto sensu, it should be assessed whether the cost of the restriction is proportionate to the benefits which are expected to be reached. ${ }^{101}$ In reviewing the core idea of the proposed policy, instead of repeating the aforementioned expected benefits and potential costs of language diversity, justification of the policy, and thus the answer to the proportionality test, can be found in the fact that none of the Member States, nor the European Union as a whole, question the necessity of limiting the number of languages in patent applications. The latest discussion among the Member States and the EU does not focus on the objectives of the EU patent system, as they are already well recognised, neither does it focus on the inevitability of language limitation. It is no longer disputed that such limitation is proportionate to the benefits; the only question is which languages should be designated as official ones. The necessity test shows not only that the limitation is necessary, but that limitation to the particular languages proposed in the Translation Proposal is also necessary. With the disputed choice of languages being necessary to obtain the recognised EU objectives, and with all the actors supporting the underlying idea of language limitations, the proposed Translation Proposal complies with the principle of proportionality.

Therefore, even if the proposed language system does fall under the scope of the non-discrimination principle, the restriction is justified under the requirements for the legality of such a limitation. The restriction is based on the Treaty, has a recognised, legitimate aim of technological and scientific advancement, does not go beyond what is necessary to achieve that aim, and does not endanger the essence of the right to language diversity.

\section{III.4. Internal market and distortion of competition}

While the first paragraph of article 326 TFEU sets a general provision on compliance with Union law, the second paragraph emphasises that enhanced cooperation must not have a detrimental effect on the internal market:

Such cooperation shall not undermine the internal market or economic, social and territorial cohesion. It shall not constitute a barrier to or discrimination in trade between Member States, nor shall it distort competition between them.

This caveat seems to send a clear message: although a group of Member States is allowed to integrate, the general objective of establish-

101 Tor-Inge Harbo, 'The Function of the Proportionality Principle in the EU Law' (2010) 16(2) European Law Journal 158. 
ing the internal market is still a higher priority and it must not be hindered by the use of enhanced cooperation.

\section{III.4.a) Barriers to trade}

Regarding barriers to trade, the unitary patent protection facilitates better market integration of the area it covers. However, it should be assessed whether enhanced cooperation, namely limiting the unitary patent protection to twenty-five Member States, raises barriers to trade in respect of the non-participating Member States, as Italy and Spain claim. ${ }^{102}$

Unitary patent protection covers the territory of only twenty-five Member States and does not include the territories of Italy and Span, thus partitioning the internal market into three separate protection areas. The aspect in which the use of unitary patent protection potentially hinders trade concerns the products protected just in the participating, or just in one or both of the non-participating, Member States. Such territorial divergence in protection could discourage or even prevent the import of products from one area to another and impede the free movement of goods. ${ }^{103}$

At the moment, the same problem exists with regard to all twentyseven national territories. This is not just a hypothetical problem, either. The high costs and complexity of national validation required in the existing system result in a patent being protected on average on the territory of only five Member States, ${ }^{104}$ hence partitioning the internal market not as an exception, but as a rule.

Still, the European Court of Justice has taken the position that these national systems and their requirements to file translations into national languages do not impede intra-Community trade. ${ }^{105}$ The Court accepted the argument claiming that the costs and complicated validation requirements might result in a patent being protected only in some Member States, thus dividing the market into a zone of protection and a free zone. ${ }^{106}$ Moreover, it acknowledged that having patent protection in only some Member States causes differences in the movement of goods. ${ }^{107}$ But the Court then emphasised that such differences depend on 'the actual, unforeseeable decisions taken by each of the operators in

\footnotetext{
102 Spain (n 5) point 3.2; Italy (n 5) fourth argument.

103 Exclusivity is the essence of the rights that patents confer on their proprietor, and where the import of products which would infringe the patent can be opposed.

104 See III.3; see also n 86.

105 Case C-44/98 BASF [1999] ECR I-06269.

106 ibid, para 17.

107 ibid, para 20.
} 
the light of the economic conditions existing on the various markets', ${ }^{108}$ which makes them too uncertain and too indirect to be characterised as creating obstacles to trade in the meaning of prohibition of quantitative restrictions or measures having equivalent effect. ${ }^{109}$ Consequently, the division of the market caused by the existence of twenty-seven different national systems was claimed not to undermine the internal market.

Unitary patent protection creates a third level of patent protection, not to replace but to supplement the existing European and national systems. Furthermore, it is only the territory of such protection that is limited to participating Member States, as the unitary effect can be obtained regardless of the residence or nationality of the patent proprietor. The choice of patent system and the area for protection are still completely dependent upon the decision of the patent proprietor. The effects of these decisions should, according to the Court's case law, be considered too uncertain and too indirect to impede cross-border trade.

Additionally, the possibilities for heterogeneous patent protection increase with the number of areas for which the patent can be protected, so three protection areas should be considered more convenient than twenty-seven. In addition, it is more probable that the product will not be protected for the entire internal market with only national systems existing than with a unitary patent protection available. The main ambition of the proposed system is to make patent protection more feasible by lowering the overall cost for patent protection over the entire territory of the internal market, ${ }^{110}$ and such savings could have a spill over effect on the Italian and Spanish market as well.

Perception of the unitary patent protection system as an obstacle to trade would mean applying much stricter criteria than those used for the current system. The differences in trade caused by fragmented patent protection have so far been considered as not to infringe the free movement of goods. The proposed unitary protection does not create new disparities; on the contrary, it works to eliminate them. It completely abolishes the borders between the participating Member States, and could have a positive effect on the non-participating ones as well. ${ }^{111}$ Of course, the integration of the internal market would be better if unitary patent protection was available for the entire Union territory, and if that option was possible, enhanced cooperation would not be used. ${ }^{112}$ If the detri-

\footnotetext{
108 ibid.

109 ibid, para 21.

110 See III.3.

11 Enrico Bonadio, 'The EU Embraces Enhanced Cooperation in Patent Matters: Towards a Unitary Patent Protection System' (2011) 3 European Journal of Risk Regulation 416, 420.

112 The last resort principle would prevent the use of enhanced cooperation. See III.2.
} 
mental effect is to be assessed in the light of whether it would be better if all Member States cooperated, it is difficult to conceive of a case of enhanced cooperation in the area of the internal market that would pass such scrutiny. ${ }^{113}$ The area of the internal market has been considered eligible for enhanced cooperation ever since the Treaty of Amsterdam, ${ }^{114}$ and a change of approach on that issue would be legally unfounded.

\section{III.4.b) Distortion of competition}

Italy and Spain claim that the choice of languages in the Translation Proposal distorts competition by giving a competitive advantage to business in the countries whose official language is English, French or German. ${ }^{115}$ Both countries would rather have English as the only official language of patent applications, as they consider that it would put all (non English speaking) companies on an equal footing. In addition, Spain submitted a plea claiming that the proposed system disrespects Spain's interests. In this regard, a closer look should be taken at the impact the proposed language regime will have on competition between companies from English, French or German speaking countries and those from other countries. The issue of Spain's interest, and the appropriateness of assigning only the English language, should be considered.

In the proposed system, a patent application can be submitted in any language, but has to be translated into English, German or French. The costs of translation in one of these languages for the application submitted in any other of the Union's official languages will be reimbursed up to a certain ceiling. ${ }^{116}$ Such reimbursements are to be financed from the renewal fees for unitary patent protection. Furthermore, the proposed transitional period is of crucial importance here. For twelve years after the proposed legislation comes into force, patents in French or German will have to be submitted with an English translation, and patents in English with a translation into any other Union language. ${ }^{117}$ The point of this transitional period is to wait until high quality translation machines are available. After the transitional period expires, the requirement for the mentioned additional translations will be abolished, and the translation machines will translate all applications into all the Union's languages. ${ }^{118}$

\footnotetext{
113 This is the first case of enhanced cooperation in the area of the internal market, as the Rome III Regulation concerns the Area of Freedom, Security and Justice.

114 The Amsterdam Treaty, the Nice Treaty and the Lisbon Treaty respectively broadened the scope of the application of enhanced cooperation.

115 Italy (n 5) argument 4; Spain (n 5) point 3.2.

116 Art 5 TP (n 16).

117 Art 6 TP (n 16).

118 ibid.
} 
Therefore, during the transitional period, companies from countries that do not share the official patent application languages can submit the patent application in any Union language, including Italian and Spanish. They will have to translate it into English, French or German, but will also receive a reimbursement of that cost. If they choose to translate it into English, there will be no further requirements. On the other hand, companies from English, French or German speaking countries can submit a patent application in their languages, but have to accompany it with a translation in English, for which they will not be reimbursed. In effect, it does not seem likely they will have any competitive advantage regarding the language of application, let alone one sufficient to cause a distortion of competition.

After the transitional period, all languages will still be permitted for patent application, but high quality translation machines would then translate them in all Union languages. In this phase, all companies will truly be on an equal footing.

Still, it seems that both Spain and Italy would support a proposal designating only English as the official language of patent applications. Some stakeholders have also expressed the desire for a unilingual, English model, ${ }^{119}$ since English is the customary language in the field of international research, ${ }^{120}$ commonly used in technical fields and by most patent experts. ${ }^{121}$

The option of a unilingual model was reviewed in the Impact Assessment of 2010, ${ }^{122}$ but rejected when it was asserted that it would be detrimental to the users of the current EPO regime. Companies that at the moment file applications in French and German would face additional costs and logistic complexities, as they would have to undergo significant changes of practice. ${ }^{123}$ These companies are not only French or German businesses, as $48 \%$ of the applications submitted to the EPO from the European Union use one of these two languages. ${ }^{124}$

\footnotetext{
119 Commission Staff Working Paper, Impact Assessment, SEC (2011) 482/2.

120 Riley (n 82) 303.

121 UNICE Position Paper on the Green Paper on the Community Patent and the Patent System in Europe (1997) Intellectual Property Rights Vol.7, No.8 <http://www.unice.org/ unice/docum.nsf/all+by+description/041A4F216C32AFA6CI 2568B0004 A76D3/\$File/ Ipr-doc.pdf.> accessed 17 March 2012.

122 Impact Assessment (n 85).

123 ibid.

124 Internal EPO data 2009.
} 
There are even more reasons for not using only English. ${ }^{125}$ Germany and France submit most patent applications in Europe, ${ }^{126}$ and are not reimbursed for the costs under the currently proposed system. If English was the only language, there would be no ground to deny the proprietors who use French or German in their applications fair reimbursement for translation costs, as received by all users not sharing the official language. This would significantly raise the number of reimbursements and result in an increase in the renewal fees from which such payments are administered, thus having a negative effect for all users of the unitary patent protection.

Under the current proposal, English is given an enhanced role, as companies not using German of French can submit an application in their own national language and supplement it only with an English translation. Spanish companies at the moment use English in 93\% of their applications, and will be allowed to continue doing so in the future. ${ }^{127}$ However, Spain still considers that its rights are not respected. Article 327 TFEU refers to the impact enhanced cooperation is allowed to have on the non-participating Member States: Any enhanced cooperation shall respect the competences, rights and obligations of those Member States which do not participate in it'. Ever since enhanced cooperation was introduced, it has been considered that use of enhanced cooperation must not harm non-participating Member States. The Amsterdam Treaty has been setting a high threshold for the rights of non-participating Member States, by specifying that enhanced cooperation "shall not affect the competences, rights, obligations and interests of those member states which do not participate therein'. ${ }^{128}$ This provision was changed in the Nice Treaty, which replaced the term 'affect' with 'respect', as it stands today. ${ }^{129}$ This was clearly not just a slight terminological modification; it mitigated the requirement. ${ }^{130}$

In effect, even if the Translation Proposal does not take the interests of Spanish companies into account, this does not amount to disrespect for the rights of Spain and hence an infringement of article 327 TFEU.

\footnotetext{
125 The issue of legal certainty can also be raised. The disclosure of information is the main purpose of patents, and having a translation into only one language, especially English, is not as effective as having it in at least two.

126 EPO statistics (n 93).

127 EurActiv Network, 'Rapporteur: Italy is Substantially Isolated on Patent Issue' (24 June 2011) <http://www.euractiv.com/innovation-enterprise/rapporteur-italy-substantiallyisolated-patent-issue-interview-505917> accessed 17 March 2012 .

128 Article 41 para 3 Treaty of Amsterdam [1997] OJ C340/ 1 (hereinafter Amsterdam Treaty) (emphasis added).

129 Article 41 of the Treaty of Nice [2001] OJ C80/1 (hereinafter Nice Treaty).

130 Cantore (n 38) 6, quoting Rossi and Craig.
} 
When deciding on the case of the Community Trademark Regulation, the Court has reflected upon the issue of languages used in intellectual property systems. ${ }^{131}$ The fact that intellectual property is not created for the benefit of all citizens, but for economic operators, was taken into account. Users of the system are not obliged to utilise it; ${ }^{132}$ they do so in the context of their professional activity that leads to making profit. ${ }^{133}$ Consequently, the argument that the users must bear the costs was upheld. ${ }^{134}$ The Court then described the language regimes of the intellectual property systems as the 'result of a difficult process which seeks to achieve the necessary balance between the interests of economic operators and the public interest in terms of the cost of proceedings'. ${ }^{135}$ The conclusion was that limiting the regime to the most widely known languages is proportionate, and the suggestion of using only one language was rejected. This decision authorises legislation to derogate from the interests of economic operators, as these interests are not absolute, but have to be balanced with other interests and circumstances.

The Translation Proposal does not create a competitive advantage for companies from English, French or German speaking countries, nor does it diminish the competitive advantages of companies from other countries. The English language model is not necessary for the preservation of competition; on the contrary, it would harm all the users of the system. Lastly, even if enhanced cooperation does not respect Spain's interest, this does not result in a violation of rights, as the Court's case law clearly shows that the interests of a Member State do not amount to a right. Overall, all aspects of enhanced cooperation comply with the prohibition of undermining the internal market.

\section{The Unitary Patent Protection Proposal - a correct legal basis}

\section{IV.1. Legal basis for unitary patent protection}

The European Union's competence to create new forms of intellectual property has been recognised for over 20 years. Although previous versions of the Treaties did not explicitly provide powers to do so, establishing legal instruments for protection of intellectual property was considered to fall under article 352 TFEU, a residual legal basis for meas-

\footnotetext{
131 Kik (n 76).

132 ibid, para 88.

133 ibid, para 89.

134 ibid.

135 ibid, para 92.
} 
ures necessary to attain the Treaties' objectives. ${ }^{136}$ The European Court of Justice repeatedly confirmed this approach, ${ }^{137}$ and article 352 was invoked for the creation of the Community trademark ${ }^{138}$ and the Community design. ${ }^{139}$

The issue was simplified with the Lisbon Treaty, ${ }^{140}$ as article 118 TFEU now explicitly authorises the European Union to establish measures creating European intellectual property. The first paragraph of article 118 TFEU defines both the object to be created and the goal which that object is to achieve:

[T]he European Parliament and the Council, acting in accordance with the ordinary legislative procedure, shall establish measures for the creation of European intellectual property rights to provide uniform protection of intellectual property rights throughout the Union.

If this provision is to be applied, the aim of providing unitary protection must be achieved by means of creating European intellectual property rights, with the term 'creation' unquestionably referring to the making of something new.

Article 118 TFEU is invoked as a legal basis for unitary patent protection in the Authorising Decision, and consequently in the Unitary Patent Protection Proposal. Although recourse to article 118 TFEU seems an appropriate choice for the creation of unitary patents, it is doubtful whether the Unitary Patent Protection Proposal complies with the requirements specified in the first paragraph of article 118 TFEU, namely whether it introduces a new intellectual property right.

\section{IV.2. What constitutes a new intellectual property right?}

To ascertain whether the Unitary Patent Protection Proposal is correctly grounded on article $118 \mathrm{TFEU}$, it is first necessary to estab-

\footnotetext{
136 Article $235 \mathrm{EEC} / \mathrm{EC}$, then art $308 \mathrm{EC}$ as from the entry into force of the Treaty of Amsterdam, now article 352 TFEU.

137 Case C-350/92 Spain v Council [1995] ECR I-1985, para 24; Opinion of the Court 1/94 ECR I-5267, para 59; Case C-377/98 Netherlands $v$ Parliament and Council [2001] ECR I07079, para 24.

138 Council Regulation EC/40/94 of 20 December 1993 on the Community trade mark [1994] OJ L11/1.

139 Council Regulation EC/6/2002 of 12 December 2001 on Community designs [2002] OJ L3.

140 Simplified because there is no need to prove the necessity of the measure, and because of a change in legislative procedure: art 352 TFEU requires unanimity in the Council and gives the European Parliament an advisory role, while art 118 TFEU prescribes an ordinary legislative procedure for the introduction of new rights; a special legislative procedure with the Council acting unanimously is required only for translation agreements.
} 
lish what constitutes a new intellectual property right. The European Court of Justice created a body of case law regarding the issue when deciding on the legal basis for previously introduced intellectual property protection mechanisms, and has set a high threshold for whether certain modifications amount to creating a new intellectual property right.

In this light, the Directive on biotechnological inventions only approximates laws, and does not create a new right. ${ }^{141}$ Even though this directive changed an essential, substantive element of patents by altering the scope of products eligible for patent protection, the Court nonetheless perceived patents issued under the directive as 'old' national patents. The decisive factor was that they are still granted through national procedures and derive their force from national law. Additionally, it was significant that the creation of a Community patent is neither the purpose nor the effect of this directive. ${ }^{142}$

Likewise, the Regulation creating a supplementary protection certificate, ${ }^{143}$ which prolongs the duration of patents, was also considered not to give rise to a new right. The length of the protection period is fundamental for defining the concept of patents, but the Court emphasised that it does not affect the substance of rights. ${ }^{144}$

On the other hand, the Community trademark is appropriately recognised as a new EU form of intellectual property. ${ }^{145}$ The Community Trademark Regulation provides a new title, regulates both procedural and substantive trademark law, priority, use and licensing of trademarks, as well as conditions for revocation and invalidity. ${ }^{146}$

Therefore, when assessing whether the legislation introduces a new intellectual property right, attention should be paid to its aims and effects, as well as whether it fully governs the conditions and procedure for granting, and for the existence and substance of, the right in question.

${ }_{141}$ Directive 98/44/EC of 6 July 1998 of the European Parliament and of the Council on the legal protection of biotechnological inventions [1998] OJ L213/13.

142 Spain v Council (n 137) para 25.

143 Council Regulation EEC/1768/92 of 18 June 1992 concerning the creation of a supplementary protection certificate for medicinal products [1992] OJ L182/1.

144 Case C-377/98 Netherlands v Parliament and Council [2001] ECR I-07079, paras 15 and 27.

145 Confirmed in Spain $v$ Council (n 137) para 23.

146 Council Regulation EC/207/2009 of 26 February 2009 on the Community trade mark [2009] OJ L78/1. 


\section{IV.3. Application to the proposal}

Under the criteria established by the European Court of Justice, it is no longer certain that the Unitary Patent Protection Proposal actually introduces a new intellectual property right and can thus be based on article 118 TFEU.

The very titles of the Decision authorising enhanced cooperation in the area of the creation of unitary patent protection and the Proposal for a Regulation implementing enhanced cooperation in the area of the creation of unitary patent protection reveal that they focus directly on the goal of unitary protection. Both documents entirely leave out mention of the creation of rights when rephrasing article 118 in their preambles, and the Unitary Patent Protection Proposal reveals why: the aim of article 118 is to be achieved by giving unitary effect to European patents granted by the EPO. ${ }^{147}$ Consequently, the Unitary Patent Protection Proposal does not introduce a new patent title.

The main added value of the proposed system is providing a patent proprietor with the possibility to register unitary effect for the European patent already granted by the EPO. ${ }^{148}$ Such a European patent with unitary effect could be limited, transferred, revoked or could lapse only for the entire territory of all Member States taking part in enhanced cooperation. ${ }^{149}$ Regardless of its possible practical importance, this novelty only adds another characteristic to the existing, non-EU instrument of the European patent. ${ }^{150}$

The nature of unitary protection is accessory to the European patent, ${ }^{151}$ which is granted according to the rules, procedures and conditions provided by the EPC and implemented by the EPO. ${ }^{152}$ Therefore, all European patents go through the same established EPO procedure and have to abide by the same EPC substantive provisions. The only change the Unitary Patent Protection Proposal introduces regarding acquisition of the right is the abolishment of national validation. National validation is required after the grant of European patents, but will not be a prerequisite for European patents with unitary effect. ${ }^{153}$ The validation

\footnotetext{
147 Preamble, para 7, UPPP (n 16).

148 Art 3 para 1 UPPP (n 16).

149 Art 3 para 2 UPPP (n 16).

150 www.unitary-patent.eu, 'Legal Basis for the Unitary Patent: Do Not Play with Fire!' (5 July 2011) <http://unitary-patent.eu/content/legal-basis-unitary-patent-do-not-playfire > accessed 1 March 2012.

151 Art 3 para 3 UPPP (n 16).

152 Art 2 b) and c) UPPP (n 16).

153 Arts 4 and art 10 para 4 UPPP (n 16).
} 
procedures consist of registering a patent in the national patent office, by paying a registration fee and publishing a translation in a national language. ${ }^{154}$ The Unitary Patent Protection Proposal provides an alternative possibility of registering a European patent with unitary effect, which will be done solely at the EPO. ${ }^{155}$ Although the elimination of national validation could contribute to cost effectiveness, the change is purely administrative.

On the other hand, substantive questions of validity, infringement and limitation through compulsory licence, crucial for the existence of a right after its granting, are not regulated by the Proposal. They remain to be governed by national laws, ${ }^{156}$ resulting in the European patent with unitary effect not having an autonomous character. ${ }^{157}$

Consequently, the granting phase remains to be governed by the $\mathrm{EPC}$, while the post-granting life of the patent is still subjected to national provisions. The Unitary Patent Protection Proposal refers to unitary protection as an instrument of its own, ${ }^{158}$ and fails to address issues necessary for the genuine creation of rights. It does not, in its aim or effect, introduce a new European intellectual property right and therefore cannot be based on article 118 TFEU.

At the moment, this issue is not tackled by the claims of Italy and Spain, as they deal only with the Authorising Decision. But if the Unitary Patent Protection Proposal is to be adopted without a proper legal basis it would be in breach of law, and further actions for annulment can be expected. As the annulment of the implementation act would render the entire enhanced cooperation meaningless, this mistake should be corrected before the proposal is adopted.

\section{IV.4. Possible ways forward}

There are two ways to fix the wrong choice of legal basis for a piece of legislation. The first is to find a different, proper legal basis in the Treaties, and the second is to amend the proposed legislation to comply with the requirements of the invoked legal basis.

\footnotetext{
154 Rodriguez (n 36) 575; Art 65 para 1 EPC (n 8).

155 Art 12 para 1 b) UPPP (n 16).

156 Preamble paras 8 and 9 UPPP (n 16).

157 Helena Olsen, 'European Patent with Unitary Effect: Reduction of High Costs Relating to Patents Valid throughout the EU?' (2011) Patents in Europe 11, 40.

158 Preamble para 1 UPPP (n 16).
} 


\section{IV.4.a) New legal basis}

If the Unitary Patent Protection Proposal stays the same and continues to refrain from introducing a new intellectual property right, it should be based on a different legal basis from article 118 TFEU. Article 114 TFEU, providing powers for the harmonisation of laws necessary for the functioning of the internal market, and the residual legal basis of article 352 TFEU, come to mind as possible solutions.

However, keeping the proposed system which does not introduce a new patent title means that the EU is about to relinquish prospects of control over an originally EU concept of the unitary patent, thus putting the protection of EU interests and the efficiency of such a patent system at risk.

In the current version of the proposal, the EPO is endowed with the governance of patents in the pre-grant phase. It would be completely misplaced to believe that the EPO is fit to guard any of the EU's interests intertwined with patent protection, as it does not even consider itself to be subjected to the rules of EU law. ${ }^{159}$ Moreover, the EPO is assigned with not only the implementing, but also with the legislative, role. By giving unitary effect to European patents, all future amendments of the EPC are blankly accepted, as the EU has no influence over them whatsoever. ${ }^{160}$

The EU has lately been criticised for its own lack of democratic legitimacy, and in response is striving to augment the role of the European Parliament in the legislative process. ${ }^{161}$ The course of action presented in the Unitary Patent Protection Proposal runs contrary to that ambition. It suggests circumventing the legitimising role of the European Parliament for the benefit of an intergovernmental organisation frequently criticised for a lack of democratic legitimacy by academics, EPO staff, governmental studies, and even the European Parliament and the Commission themselves. ${ }^{162}$

\footnotetext{
${ }_{159}$ See EPO's 'Notice dated 1 July 1999 concerning the amendment of the Implementing Regulations to the European Patent Convention' EPO OJ 8-9/1999 (1999) 573 para 2; see also EPO's Decision of the Enlarged Board of Appeal dated 28 June 2007 G 1/06 OJ $5 / 2008$ (2007) point 6.

160 They reflect a compromise of wishes between 38 contracting states.

161 Beate Kohler-Koch, Berthold Rittberger (eds), 'Debating the Democratic Legitimacy of the European Union' (Rowman \& Littlefield 2007) 10; see also the Lisbon judgment, $2 \mathrm{BvE}$ 2/08 (2009) BVerfG.

162 Susana Borrás, Charalampo Koutalakis, Frank Wendler, 'European Agencies and Input Legitimacy: EFSA, EMeA and EPO in the Post-Delegation Phase' (2007) 29(5) Journal of European Integration 583; www.unitary-patent.eu, 'Criticism of Governance of the European Patent Office' (16 May 2011) <http://unitary-patent.eu/content/criticisms-governance-european-patent-office> accessed 2 March 2012.
} 
The post-granting phase of the patent is left for national laws, which raises concerns about the added value of unitary patent protection. Can a piece of legislation claim to introduce unitary effect without defining essential aspects of that effect any further than stipulating that it is unitary? The Unitary Patent Protection Proposal specifies that the European patent with unitary effect may be limited, transferred, revoked or may lapse only in respect of all Member States, ${ }^{163}$ but it does not regulate the transfer, revocation or lapse of rights in question. Thus, aspects vital for the existence of the mentioned unitary protection are still not regulated uniformly, and the stakes are higher as a decision made under one national law should be recognised all over the territory of unitary protection. The divergence of national legal systems is thus even more emphasised and amounts to a threat to legal certainty, an essential prerequisite of the aims envisaged for the EU patent. ${ }^{164}$ Furthermore, rights stemming from national provisions are not supplemented with the characteristics of EU law that would improve the efficiency of unitary patent protection, namely autonomy in interpretation, direct applicability and primacy in the case of conflicts. ${ }^{165}$

Therefore, the first option of changing the legal basis and keeping the Unitary Patent Protection Proposal unchanged would present a threat to the EU legal order, as the proposal entrusts patent protection to an intergovernmental institution that does not respect the autonomy and supremacy of EU law, and jeopardises democratic principles. Moreover, this proposal does not offer a satisfactory level of legal certainty.

\section{IV.4.b) Amendments to the proposal}

An analysis of the first option shows that the mistake lies not in the choice of a legal basis that requires the creation of new intellectual property, but in the content of the Unitary Patent Protection Proposal that does not introduce an autonomous EU patent.

Even before the explicit legal basis was introduced in the Lisbon Treaty, all previous drafts and discussions were aimed at an independent, EU legal instrument, referred to as a crucial element for the establishment of the internal market. ${ }^{166}$ Patent protection is intertwined with

\footnotetext{
163 Art 3 para 2 UPPP (n 16).

164 L Karamountzos, 'Community Patent and European Patent Court: State of play in the Council' (2009) <http://www.europarl.europa.eu/stoa/events/ workshop/20090317/karamountsos_en.pdf > accessed 17 March 2012.

165 Jaeger (n 45) 7.

166 Competitiveness (Internal Market, Industry and Research), Press release 17076/09 of 4 December 2009 of the $2982^{\text {nd }}$ Council Meeting <http://www.consilium.europa.eu/uedocs/ cms_Data/docs/pressdata/en/intm/111744.pdf> accessed 5 March 2012.
} 
numerous areas relevant to the European Union, ${ }^{167}$ and the creation of the European Union patent governed by EU law and under the supervision of the European Court of Justice would facilitate the proper balancing and coordination of EU patent policy with other vital issues. ${ }^{168}$ For example, additional aims of the EU patent system should be to further market integration and to produce competitive advantages for EU innovators. ${ }^{169}$

In order to reach these aims, the Unitary Patent Protection Proposal should by itself codify the EPC rules for the granting of patents. This turns out to be an even more viable option since practice shows that some EPC rules seem to require further interpretation due to the newest developments in the area of patents. ${ }^{170} \mathrm{~A}$ specific EU patent title should be introduced, and substantive patent law regarding both the granting and existence of patents should be added. This would facilitate the purposeful navigation of general developments in patent law and provide control and legitimisation of EPO decisions. ${ }^{171}$ Moreover, greater unification of patent protection would be achieved. Rules applying to a patent with unitary effect would be uniformly legislated for and interpreted, leading towards legal certainty and predictable litigation outcomes. Control over the substantive rules on patents, their administration and implementation would on the one hand preserve the interests of the EU, and on the other hand enable the EU patent system to reach the benefits of providing efficient unitary patent protection.

Therefore, the Unitary Patent Protection Proposal should introduce a sui generis patent title, as that would not only bring it into compliance with the invoked legal basis of article 118 TFEU, but would also make it more beneficial for the functioning of the EU patent system, as well as for the EU as a whole.

\footnotetext{
167 Opinion of the Court 1/09 [2011] ECR 00000 Opinion of AG Kokott, para 80.

168 General intellectual property policy (plant varieties, trade marks, etc), competition, internal market issues, regional and SME policies.

169 Jens Schovsbo, 'Constructing an Efficient and Balanced European Patent System: Muddling through' (2011) 2 <http://papers.ssrn.com/sol3/papers.cfm?abstract_id=1932690> accessed 1 March 2012.

170 The EPO's Enlarged Board of Appeal explicitly requested the legislative clarifications. See Opinion G 3/08 published on 12 May 2010: 'When Judiciary-driven Legal Development Meets Its Limits, It Is Time for the Legislator to Take Over'.

171 I Schneider, 'Governing the Patent System in Europe: The EPO's Supranational Autonomy and its Need for a Regulatory Perspective' (2009) 36(8) Science and Public Policy $619,628$.
} 


\section{Conclusion}

At first glance, it seems doubtful whether the introduction of unitary patent protection by enhanced cooperation complies with the legal requirements of such cooperation. Nevertheless, closer insight reveals that the issues contested for violations actually present the inherent characteristics of the system.

On the one hand, the introduction of cost-effective and efficient unitary patent protection has an impact on numerous issues considered to be of vital interest for the European Union. It encompasses the matter of unity of the European Union, preservation of language diversity, integration of the internal market, enhancement of competitiveness and incentives for research and development. It is a field in which various interests collide, making certain compromises essential for the establishment of the European Union patent system.

On the other hand, enhanced cooperation is in its nature an exception to the rule. If it is ever to be utilised, the territory over which it has effect and the use of European Union institutions will be restricted to the participating Member States. Accordingly, it is capable of facilitating direct internal market integration only for those Member States. However, when the reaching of consensus at the European Union level turns out to be impossible, the institute of enhanced cooperation seems better than the alternatives, namely taking no action or taking action outside the framework of the European Union.

Furthermore, it appears that the use of enhanced cooperation in the case of unitary patent protection complies with the law and respects the set safeguards. The creation of European intellectual property is an internal market measure and not an exclusive competence of the Union, as it falls under the field of shared competences and does not prevent the non participating Member States from establishing their own transnational intellectual property instruments. Enhanced cooperation is used as a last resort, as no agreement seems possible in the foreseeable future. The chosen language regime does not amount to discrimination, but even if it did, it would be a justified limitation, as it is necessary and suitable to achieve the Treaties' objectives, respects the essence of the right to language diversity and is proportionate. It would not create a competitive advantage for the countries using the designated languages and thus does not discriminate in trade or distort competition. It achieves a better integration of the internal market between the participating Member States, and, according to the Court's case law, should not be considered as creating obstacles to trade for the non-participating Member States. 
However, the implementation of enhanced cooperation is worrisome. The Unitary Patent Protection Proposal does not introduce a new intellectual property right, and thus fails to comply with the invoked legal basis. Of two ways to fix the problem of a lack of correct legal basis for the Unitary Patent Protection Proposal, the first option of changing the legal basis would mean that the shortcomings of the current Unitary Patent Protection Proposal would remain. This could prove detrimental for the efficiency of unitary patent protection, as well as for the interests of the European Union as a whole. It would be quite a missed opportunity if the legitimate case of enhanced cooperation failed to address all issues necessary for the optimal patent protection system. Therefore, the Unitary Patent Protection Proposal should be revised and accordingly amended to comply with the legal basis of article 118 TFEU.

The European Court of Justice will have the final say on the legality of enhanced cooperation, and will hopefully clarify this overlooked instrument and determine some of the conditions for its application. In the meantime, the problem of the lack of a correct legal basis for the Unitary Patent Protection Proposal must be solved, as otherwise an action for annulment can certainly be expected. 